\title{
Influence of tides on assemblages and behaviour of fishes associated with shallow seagrass edges and bare sand
}

\author{
Alistair Becker ${ }^{1, *}$, Christine Coppinger ${ }^{1,2}$, Alan K. Whitfield ${ }^{1}$ \\ ${ }^{1}$ South African Institute for Aquatic Biodiversity, Private Bag 1015, Grahamstown 6140, South Africa \\ ${ }^{2}$ Department of Ichthyology and Fisheries Science, Rhodes University, PO Box 94, Grahamstown 6140, South Africa
}

\begin{abstract}
Seagrass beds and associated fish assemblages have been the focus of a large number of past studies. However, the influence of small water depth changes due to tides on fish species along shallow seagrass bed edges is unknown. In this study an underwater video camera was deployed to examine the fish community at 3 seagrass edge (Zostera capensis) and 3 sand sites over incoming spring and neap tides in the Bushmans Estuary, South Africa. Small changes in tidally driven water depth had significant effects on the abundance of common fish taxa, with gobies decreasing and others, including mullets, increasing in abundance. These general patterns were consistent in both seagrass and sand sites, as well as during spring and neap tidal cycles. There were inconsistent differences in the abundance of common fish taxa between seagrass edges and bare sand. Importantly, when differences did occur, these were contingent on tidal stage or linked to different tidal cycles (neap or spring), highlighting that small changes in depth may influence edge effects. The behaviour of fish did not appear to be influenced by water depth, but for some taxa there were distinct differences in swimming behaviour between those individuals associated with seagrass beds and those situated over bare sand. These small temporal scale changes in water depth are a previously overlooked aspect of littoral seagrass landscapes that may be important in structuring associated fish communities.
\end{abstract}

KEY WORDS: Underwater video · Water depth · Estuary · Fish movements · Zostera capensis · South Africa

Resale or republication not permitted without written consent of the publisher

\section{INTRODUCTION}

Seagrass beds are important nursery grounds and are believed to support numerous commercial fish stocks; they therefore have both economic and conservation value (Jackson et al. 2001). Most seagrass beds are located in shallow coastal waters that are subjected to daily fluctuations in depth due to tides (Connolly \& Hindell 2006). Tides may influence animal assemblages within shallow seagrass beds by altering the accessibility of these habitats to highly mobile species such as fish.

The influence of tides on fish has received significant focus in the past, with particular attention paid to 'tidal migrations' or the synchronous movement of fish with the tide (Gibson 2003). The study of such migrations generally focuses on the movement of animals into the intertidal zone during the flood tide and the subsequent retreat as the ebb tide drains these areas. Most studies have been conducted in intertidal marshes or mangroves (e.g. Hampel et al. 2003, Ellis \& Bell 2004, Bretsch \& Allen 2006, Kimball \& Able 2007). These studies have used a range of sampling gears (e.g. fyke nets: Giarrizzo et al. 2010; minnow traps: Rozas \& Zimmerman 2000) to examine how nekton respond to tides. However, due to the logistical and practical constraints of repeated smallscale temporal sampling at a particular site, with the 
exception of a few studies from tidal marsh creeks (Bretsch \& Allen 2006), collections are usually made at relatively low frequencies, normally 1 to 4 times over a tidal cycle (Thomas \& Connolly 2001, Kimball \& Able 2007).

While the migration of fish into intertidal habitats has been the topic of previous research, the effect of tides and changing water depth along shallow patches of subtidal seagrass beds is still largely unknown. Some work has focused on the effects of depth on faunal assemblages associated with seagrass beds (Bell et al. 1992, Jackson et al. 2006). Results have been inconsistent, with most studies relying on spatially segregated 'deep' and 'shallow' sites, with depth ranges being relatively large (meters) and deeper sites often exposed to differing hydrological conditions or consisting of differing structure (Hovel et al. 2002).

Similar to intertidal examples, studies that have examined seagrass sites at different tidal depths have been based on a relatively low frequency of repeat sampling (Sogard et al. 1989, Unsworth et al. 2007). Consequently these results may reflect coarse changes in the fish community and do not relate to the effects of smaller changes in depths which shallow littoral beds experience during tidal cycles.

High temporal frequency sampling represents the best approach to studying sites that are subjected to constant changes in depth over time. However, the few studies to employ high frequency sampling within intertidal mangrove and marsh creeks (e.g. Bretsch \& Allen 2006) have used equipment that is not transferable to other habitats, therefore alternative methods are required.

Recently, new approaches have been employed in the study of estuarine fish that consist of uninterrupted observations using underwater cameras (Ellis \& Bell 2008, Becker et al. 2010, Smith et al. 2011). These methods have proved useful in obtaining data from structured habitats and at small temporal scales. Underwater videography has the added advantage in that it can collect continuous information on the behaviour of fish under natural conditions. This may help to identify processes responsible for the patterns observed in the distributions of fish in patchy habitat mosaics (Becker et al. 2010).

In this study, we test predictions regarding shallow water fish assemblages along the edge of seagrass patches and nearby bare sand and their responses to an incoming tide: (1) there will be differences in fish assemblages between seagrass edges and nearby bare sand and these will be affected by changes in water depth; (2) there will be differences in the abun- dances of common species between seagrass edges and nearby bare sand and the magnitude of these differences will be affected by water depth and tide cycles; (3) behaviour of common species will differ between seagrass edges and sand areas and will also be affected by the incoming tide.

\section{MATERIALS AND METHODS}

\section{Site description}

The Bushmans Estuary $\left(33.4^{\circ} \mathrm{S}, 26.4^{\circ} \mathrm{E}\right)$ is a large, permanently open system located in the warm-temperate region of South Africa (Fig. 1). Tides along this section of coast are mesotidal with a range $<2 \mathrm{~m}$. Because of catchment water extraction, the estuary can be considered freshwater deprived (Whitfield 2005), resulting in the lower reaches being marine dominated, with salinities almost permanently similar to seawater. These lower reaches are characterised by large shallow sand flats, subtidal seagrass beds and intertidal saltmarsh habitat. The mostly sand substrate and marine dominance results in consistently low turbidity that is conducive to underwater video studies. The focal area of this study was a side channel of the main arm of the estuary, situated approximately $900 \mathrm{~m}$ upstream of the mouth. This side channel contained numerous patches of seagrass and bare sand habitats at similar depths that could be easily sampled using a fixed remote underwater video camera.

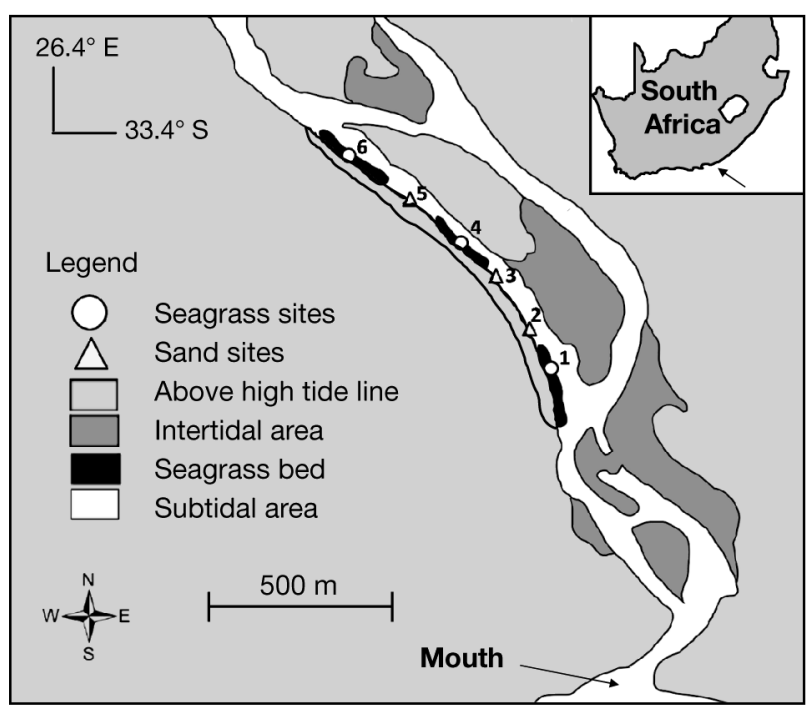

Fig. 1. Lower reaches of Bushmans Estuary showing the locations of the 6 sampling sites and the intertidal and subtidal areas. Insert shows the location of the estuary (arrow) along the South African coast 


\section{Field methods}

Fieldwork was conducted during spring and neap tide cycles between March 2010 and January 2011. Three spatially replicated sites of each subtidal habitat (seagrass edge and sand $=6$ sites in total) were similar in subtidal depths. Seagrass beds were similar in size and consisted of monospecific stands of Zostera capensis of moderate shoot density. Sites were separated by at least $50 \mathrm{~m}$, and therefore the edges of any $2 Z$. capensis patches were a greater distance apart than from the middle of a seagrass bed to its edge. This distance is far away from any adjacent habitat patch, so that they can be considered independent. Three replicate deployments were made at each site during both spring and neap tide cycles, resulting in a total of 36 deployments. To avoid potential temporal bias during the fieldwork period, sampling of sites (and therefore habitats) and tides (spring and neap) were randomly allocated over time, covering mainly the Austral autumn and winter of 2010. Water temperatures ranged between 17 and $20^{\circ} \mathrm{C}$ during the study period.

Deployments were conducted diurnally and were always commenced at least $1 \mathrm{~h}$ after sunrise and completed before sunset; each deployment lasted $4 \mathrm{~h}$ in duration. Pilot studies revealed that filming needed to commence $1 \mathrm{~h}$ after slack low tide; this allowed for sufficient water depths across the sites for the camera to be fully submerged during spring tides. Only the flooding tide was sampled, as our hypotheses are based on examining how fish colonise shallow habitats which are subjected to tidal induced increases in depth. The entire tidal cycle was not fully completed during daylight hours often enough to allow comparisons between incoming and outgoing tides. A single low lux colour camera was mounted on a small bracket that could be driven into the substrate and remain underwater, even at very shallow depths $(\sim 20 \mathrm{~cm})$. The camera was connected via a $40 \mathrm{~m}$ cable to a shore-based Sony (model GVD1000E) video recorder and was angled parallel to the substrate. The field of view included the highest levels of the water column during the latter stages of the deployments. The camera was positioned so that it faced parallel along the edge of the seagrass bed with an unobstructed field of view at all seagrass sites. Therefore, data collected at these sites represents 'seagrass edge' (Jelbart et al. 2006), and fish observed in these locations can be considered to be associated with the seagrass-sand interface. Because edge effects may differ among locations around seagrass patches (Smith et al. 2008), the camera was positioned on the shoreward side of the bed and along the upstream edge at all seagrass sites.

Once the camera was positioned, an acclimation period of 10 min was allowed before filming commenced. A marked pole provided depth measurements $(\mathrm{cm})$ at the location of the camera and these were taken at 15 min intervals throughout each deployment. Turbidity can be highly variable, both spatially and temporally within estuaries, making it important in underwater video studies to ensure that visibility is consistent (Becker et al. 2010). Accordingly, water samples were collected 3 times throughout each deployment and processed in the laboratory so that turbidity levels between sampling occasions could be compared. Reduced visibility occurred on rare occasions during sampling and was driven by localised coastal upwelling (Cole \& McQuaid 2010), which introduced turbid marine water to the estuary during the incoming tide. Turbidity levels exceeded 6 nephelometer turbidity units (NTU) on these occasions and deployments were subsequently abandoned.

Tides were classified such that sampling events for 'Spring Tides' occurred within $4 \mathrm{~d}$ before or after the highest amplitude spring tide within a lunar cycle. Similarly 'Neap Tides' were defined as occurring within $4 \mathrm{~d}$ before or after the smallest amplitude tide within a lunar cycle. However, most samples were collected within $2 \mathrm{~d}$ before or after either the maximum or minimum amplitude tides.

\section{Analysis of video footage}

Video footage was stored onto external hard drives and viewed using Adobe Premier v6.0. Fish were identified to the lowest possible taxonomic level. Mugilids are particularly diverse in South African estuaries (Whitfield 1998) and positive identifications were made on occasions which included Liza dumerili, Liza tricuspidens and Mugil cephalus. However, it was not always possible to identify individuals to species from the video footage; as such, they were grouped together at the Family taxonomic level. A similar approach was adopted for 2 species within the Family Gobiidae (Psammogobius knysnaensis and Glossogobius callidus) and Soleidae (Solea bleekeri and Heteromycteris capensis), where there was sometimes low confidence in species identification.

Relative abundance of each taxon was calculated using the MaxN approach (Cappo et al. 2007, Watson et al. 2009) where relative abundance is defined as the maximum number of fish present in the field of 
view at the same time. This approach does not attempt to estimate total abundance at a site, but rather produces a 'relative abundance' measure which is likely to be conservative because not all individuals are necessarily counted. Importantly though, it eliminates the chances of counting the same fish repeatedly while still providing a measure of abundance which is more informative than simply reporting presence/absence. Each $4 \mathrm{~h}$ deployment was divided into 16 equal 15 min time periods, referred to hereafter as 'slots', with 4 slots within each consecutive hour. For each deployment a separate MaxN value was calculated for each taxon during each of the 16 slots. This normally resulted in separate frames being selected for each taxon.

The behaviour of every fish was also noted and placed into one of 4 broad behavioural categories developed by Becker et al. (2010) and included (1) 'Slow Meandering' (meandering through the field of view without stopping), (2) 'Start Stop' (swimming into view, stopping then moving on), (3) 'Rapid Swimming' (rapidly passing through the field of view), and (4) 'Feeding' (clearly feeding off the benthos or in the water column). If more than one behavioural category was displayed (e.g. Start Stop and Feeding) then the behaviour which the fish displayed for the majority of the time it was within the field of view was used. While these categories are broad, they have proved useful in examining how basic fish behaviour can differ among habitats and provide information relating to the way fish use various habitats (Becker et al. 2010).

\section{Statistical analyses}

Data was analysed in 2 ways:

(1) To test the hypothesis that fish assemblages differ between habitats over the incoming tidal period (i.e. hours) and tidal cycles (neap or spring), repeated measures, permutational multivariate analysis of variance (PERMANOVA) using the Primer 6+ software (Anderson et al. 2008) was conducted. Analyses were based upon Bray-Curtis dissimilarity measures constructed from untransformed data and included 9999 permutations. A dummy value of 0.01 was added to the dataset to compensate for samples containing zero fish and was appropriate for our raw data values. For clarity, and to simplify the PERMANOVA model, each slot was grouped into 1 of 4 'Hours' (with slots 1-4 forming Hour 1, slots 5-8 forming Hour 2, slots 9-12 forming Hour 3, and slots 13-16 forming Hour 4). MaxN for the taxon within each hour was calculated by taking the mean of the 4 slots within each hour and is referred to as 'mean MaxN' or mMaxN. This is preferable to taking the maximum number (i.e. MaxN) over these greater time periods, as misleading data can be generated on the average abundance over the hour, particularly for schooling species (Becker et al. 2011, Smith et al. 2011). The design then included 4 factors: 'Tidal Cycle' (2 levels: spring and neap; fixed), 'Habitat' (2 levels; sand and seagrass; fixed), 'Site' (3 levels; random, nested within Habitat), and 'Hour' (4 levels; fixed). Because there is no replication of 'Hours', the highest-order interaction which included this factor was removed from the analysis (Anderson et al. 2008).

(2) There was sufficient data on the 4 most common taxa (Mugilidae, Rhabdosargus holubi, Atherina breviceps and Gobiidae) to permit individual analysis to be performed. This allowed us to test the hypothesis that relative abundances of these 4 common taxa differed between tidal cycles, habitats, and over the incoming tide. A 3-way, repeated measures ANOVA was employed consisting of the following factors: 'Tidal Cycle' (2 levels, spring and neap, fixed); 'Habitat' (2 levels, sand and seagrass, fixed); and the repeated factor 'Hours' (4 levels, Hour 1-4, fixed). 'Site' effectively acted as a blocking factor. Sphericity was tested using Mauchly's tests. When data failed to meet this assumption, Greenhouse-Geisser adjusted F-tests were used (Quinn \& Keough 2002). Post hoc Student-Newman-Keuls (SNK) tests were used for pairwise comparisons to determine the direction of differences.

The number of behavioural observations for some Hours was occasionally low for each taxon of interest. When we attempted to formally analyse the data using chi-squared contingency tables, expected frequencies were often below 5 and therefore prohibited our ability to generate reliable tests of this categorical data (Quinn \& Keough 2002). We have still included the data descriptively (see Table 4).

\section{RESULTS}

\section{Turbidity and tidal depth}

Water within the lower reaches of the Bushmans Estuary was generally clear, resulting in overall low NTU readings at both sand sites and along the seagrass edges (Fig. 2). The maximum turbidity recorded was 3.4 NTU, however most recordings fell between 1.6 and 2.2 NTU (Fig. 2). These low turbid- 


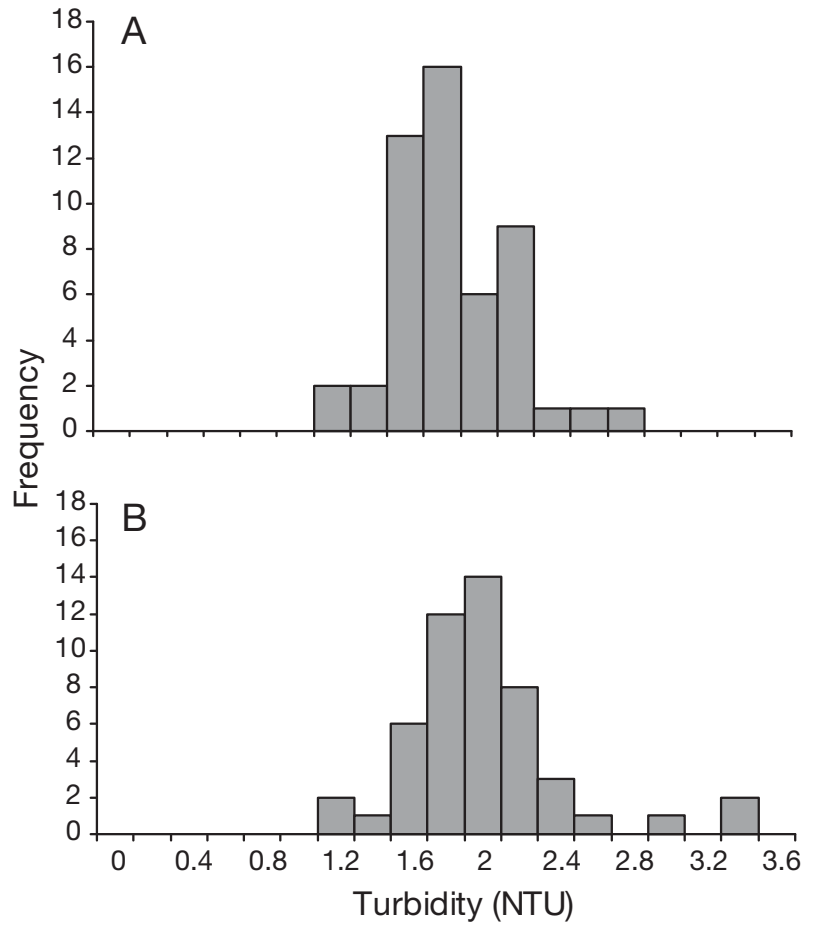

Fig. 2. Frequency of turbidity levels (NTU), pooled across all tide cycles within Bushmans Estuary within (A) seagrass edge sites and (B) sand sites

ity values corresponded to consistently clear videos that allowed for a field of view that extended approximately $2 \mathrm{~m}$ from the camera throughout the deployments. Therefore the ability to see fish could be excluded as a potentially confounding factor among sites or between habitats.

There were clear differences in mean depths between spring and neap tide cycles at the start and

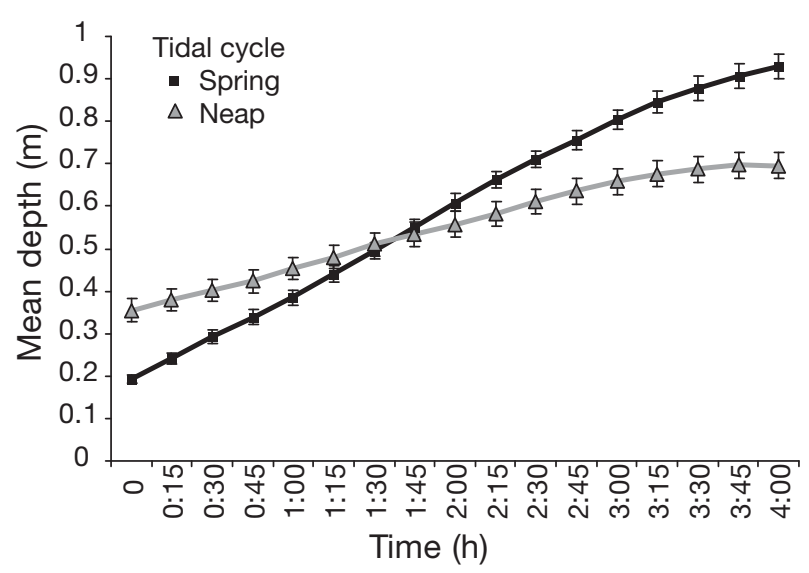

Fig. 3. Mean $( \pm \mathrm{SE})$ depth within Bushmans Estuary during spring and neap tidal cycles

end of the deployments, as well as the rate of change (gradient). Mean depths were similar during both tide cycles approximately $1.5 \mathrm{~h}$ following the commencement of the filming (Fig. 3). Replicate depths within each slot for both spring and neap tides were consistent, resulting in a low standard error.

\section{Effect of tide and habitat on fish assemblages}

A total of 12 fish taxa were recorded during the 36 deployments within the Bushmans Estuary (Table 1). The most abundant taxon was Atherina breviceps, which were often observed forming large schools. The most commonly encountered taxon however was mullet (Family: Mugilidae), which occurred in 164 of the 576 slots throughout the course of the study (Table 1). Most taxa were observed in both habitats,

Table 1. Fish taxa observed within the sand and seagrass sites of Bushmans Estuary (N: taxa observed only during neap tides; S: taxa observed only during spring tides; B: taxa observed during both neap and spring tides). Total number of recorded slots for each fish taxon is pooled across all sites and sampling occasions

\begin{tabular}{|c|c|c|c|c|c|}
\hline Scientific name & Common name & $\begin{array}{l}\text { Sand sites } \\
\text { (no.) }\end{array}$ & $\begin{array}{c}\text { Seagrass sites } \\
\text { (no.) }\end{array}$ & Tidal cycles & $\begin{array}{l}\text { No. of slots } \\
\text { (max. 576) }\end{array}$ \\
\hline Atherina breviceps & Cape silverside & 3 & 3 & B & 131 \\
\hline Clinus superciliosus & Highfin clinid & 1 & 2 & $\mathrm{~S}$ & 12 \\
\hline Diplodus capensis & Blacktail & 3 & 3 & $\mathrm{~B}$ & 69 \\
\hline Gobiidae & Gobies & 3 & 3 & $\mathrm{~B}$ & 153 \\
\hline Lithognathus lithognathus & White steenbras & 2 & 0 & $\mathrm{~B}$ & 3 \\
\hline Mugilidae & Mullets & 3 & 3 & $\mathrm{~B}$ & 164 \\
\hline Ostraciidae & Boxfishes & 0 & 1 & $\mathrm{~N}$ & 1 \\
\hline Pomadasys commersonnii & Spotted grunter & 3 & 2 & B & 24 \\
\hline Rhabdosargus holubi & Cape stumpnose & 3 & 3 & $\mathrm{~B}$ & 117 \\
\hline Sarpa salpa & Strepie & 2 & 3 & $\mathrm{~B}$ & 29 \\
\hline Soleidae & Soles & 3 & 2 & B & 22 \\
\hline Syngnathus temminckii & Longsnout pipefish & 0 & 2 & B & 2 \\
\hline
\end{tabular}


although there were some exceptions, including Lithognathus lithognathus, which were only observed within sand habitat. Conversely, Syngnathus temminckii and Ostraciidae were only observed at the edge of seagrass beds, but observations of these latter taxa were rare. No piscivores were observed in either habitat over the depth ranges examined in this study.

At small temporal intervals, there was a varied response of common taxa, with fish increasing, decreasing, or showing no apparent changes in mean abundance in relation to water depths (Figs. 4 \& 5).
The mean abundance of Mugilidae increased with the incoming tide in both habitats during spring and neap tide cycles (Figs. 4 \& 5). A similar relationship was observed with Rhabdosargus holubi along seagrass edges during both tide cycles (Fig. 5). An opposite trend was observed for Gobiidae, with higher abundances recorded in shallow water depths at the beginning of the incoming tide and gradually decreasing as the water levels increased, with this trend being consistent across both habitats.

The outcomes of the repeated measures PERMANOVA test show an interaction among Tide and
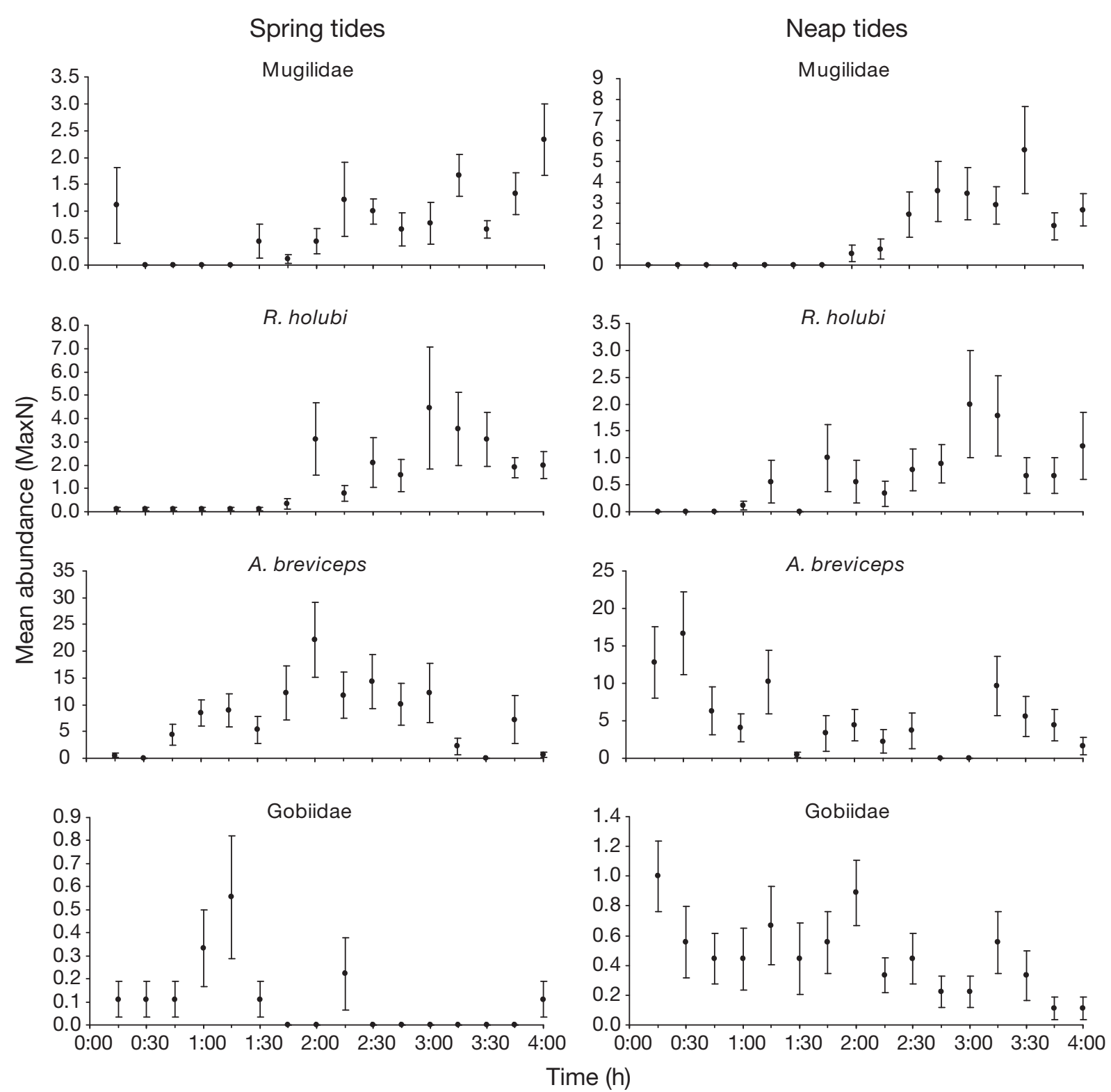

Fig. 4. Mugilidae, Rhabdosargus holubi, Atherina breviceps, Gobiidae. Mean abundance (MaxN $\pm \mathrm{SE}$ ) of 4 common taxa pooled across all replicates at the 3 sand sites $(n=9)$ of Bushmans Estuary 
Habitat for the fish community (Table 2). However, post hoc pairwise comparisons proved insignificant ( $p>0.05$ ) for each level of these factors. A strong result was found for Hour, with post hoc comparisons showing the community differing among Hours 1 and $2(p=0.024)$, Hours 1 and $3(p=0.013)$, Hours 1 and $4(p=0.02)$ as well as Hours 2 and $3(p=0.021)$. However Hour 3 remained similar to Hour $4(p=0.225)$ (Table 2). Significant differences were also recorded among Sites, but since Sites themselves were considered random, no hypothesis was developed for this factor.
Repeated measures ANOVA identified significant differences in the relative abundance of Mugilidae between Tides $(p=0.044)$ and among Hours $(\mathrm{p}=0.0001$; Table 3$)$. Abundances of mugilids were higher during neap tides (mean MaxN $\pm \mathrm{SE}=1.81 \pm$ 0.35 ) than during spring tides (mean MaxN $\pm \mathrm{SE}=$ $0.77 \pm 0.35$ ). Pairwise comparisons showed significantly higher relative abundances during the latter half of the incoming tide, with Hour 3 having significantly higher abundances than Hour 1 (SNK: $\mathrm{p}=0.0001$ and Hour $2\left(\mathrm{SNK}_{i} \mathrm{p}<0.0002\right)$ as well as Hour 4 being significantly higher than Hour 3 (SNK;
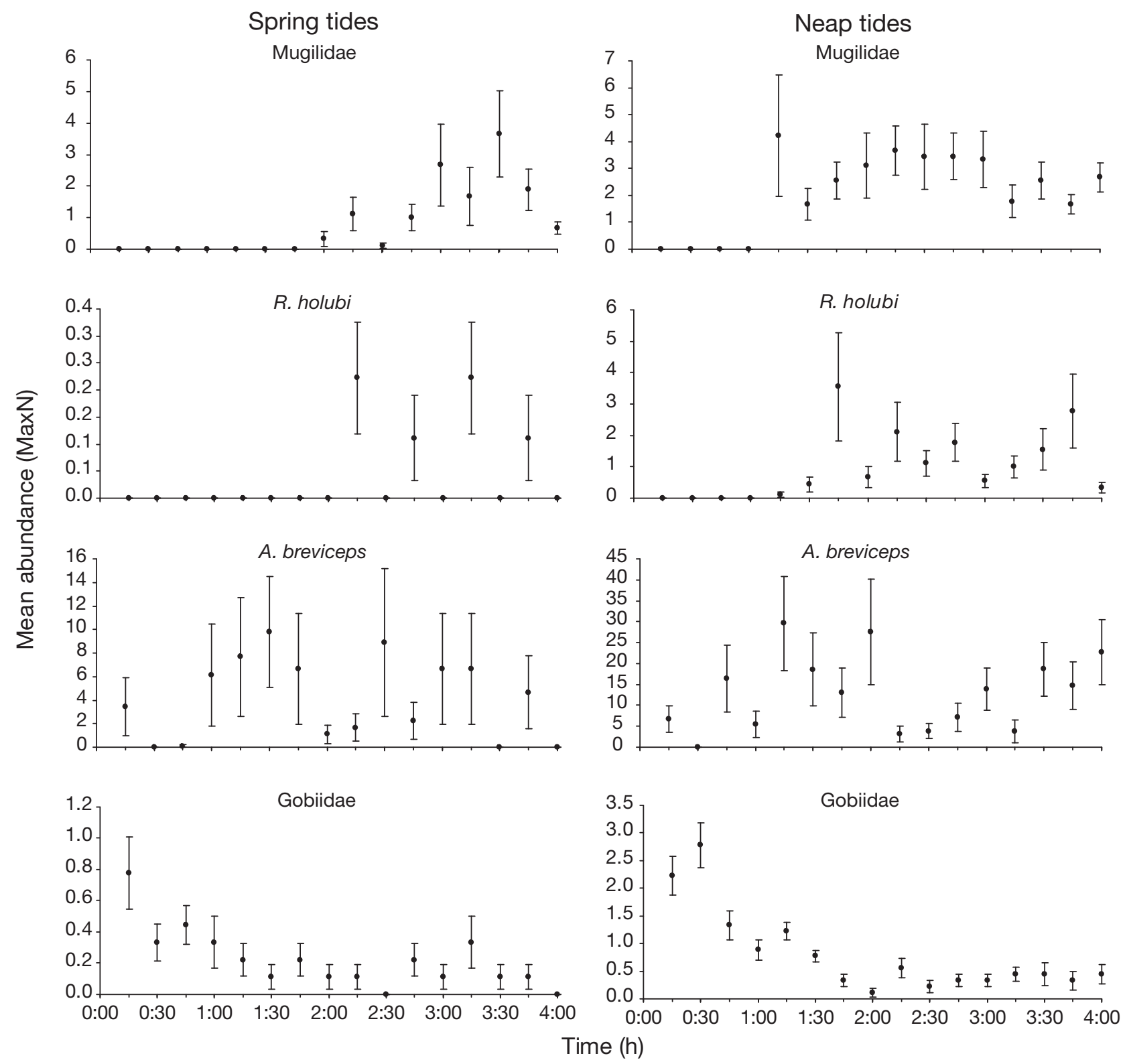

Fig. 5. Mugilidae, Rhabdosargus holubi, Atherina breviceps, Gobiidae. Mean abundance (MaxN \pm SE) of 4 common taxa pooled across all replicates at the 3 seagrass sites $(n=9)$ of Bushmans Estuary 
Table 2. Results from a repeated measures permutational analysis of variance (PERMANOVA) based on the 12 fish taxa observed (see Table 1). Significant results are shown in bold. Results of post-hoc SNK tests are shown in the bottom row of the table

\begin{tabular}{|lrrrr|}
\hline Source & df & MS & Pseudo- $F$ & p (perm) \\
\hline Tide & 1 & 11613 & 3.42 & $\mathbf{0 . 0 4 6 1}$ \\
Habitat & 1 & 10654 & 1.25 & 0.4100 \\
Hour & 3 & 14476 & 5.74 & $\mathbf{0 . 0 0 0 1}$ \\
Site $($ Habitat) & 4 & 8507.8 & 2.85 & $\mathbf{0 . 0 0 0 1}$ \\
Tide $\times$ Habitat & 1 & 16894.0 & 4.97 & $\mathbf{0 . 0 2 9 8}$ \\
Tide $\times$ Hour & 3 & 4713.6 & 1.58 & 0.0561 \\
Habitat $\times$ Hour & 3 & 2728.6 & 1.08 & 0.3788 \\
Tide $\times$ Site $($ Habitat) & 4 & 3400.7 & 1.14 & 0.2794 \\
Site $($ Habitat) $\times$ Hour & 12 & 2522.1 & 0.84 & 0.8179 \\
Tide $\times$ Habitat $\times$ Hour & 3 & 3688.5 & 1.24 & 0.2108 \\
Residual & 108 & 2984.8 & & \\
Total & 143 & & & \\
Pairwise: Hour $1 \neq 2 \neq 3$ & $=4 ;$ Tide $\times$ Habitat $=$ non- \\
significant & & & & \\
\hline
\end{tabular}

$\mathrm{p}<0.001$ ). Similar results were found for Rhabdosargus holubi, with significantly higher relative abundances during the latter stages of the incoming tides (Table 3). Pairwise comparisons showed significantly higher relative abundance during Hour 3 than Hour 1 (SNK; $\mathrm{p}=0.0015$ ) and Hour 4 than Hour 1 (SNK; $\mathrm{p}=0.0007)$. These results support the small temporal scale patterns shown in Figs. 4 \& 5 .

A significant Tide $\times$ Habitat interaction was found for Atherina breviceps (Table 3). This was due to higher relative abundances recorded at sand sites during neap tides, while abundances were higher at seagrass sites during spring tides.

Many more gobies were recorded within the sand habitat during Hour 1 compared with Hours 2 to 4 . Increased abundances of gobies between sand and seagrass edge only occurred during the first hour, resulting in a significant Hour $\times$ Habitat interaction for this taxon ( $p=0.003$; Table 3$)$.

Behaviour among the fish taxa showed considerable variability. The most dominant behaviour was the 'Start Stop' category exhibited by the gobiid species (Table 4). This regularly accounted for over $80 \%$ of observations in both seagrass and sand throughout the incoming tides during the neap and spring cycles (Table 4). Both Atherina breviceps and Rhabdosargus holubi displayed differing behaviour with regards to habitat but not tidal stage (Table 4). The dominant behaviour for both species within sand sites was almost exclusively 'Rapid Swim', regardless of tidal regime. However, when observed at the edges of seagrass beds, the dominant behaviour was 'Slow Meander' or
Table 3. Mugilidae, Rhabdosargus holubi, Atherina breviceps, Gobiidae. Results from a 3-way repeated measure ANOVA of abundance (mean MaxN) for the 4 most common taxon within Bushmans Estuary. Significant results are shown in bold ( $\mathrm{f}$ : adjusted p-values based upon Greenhouse-Geisser calculated degrees of freedom)

\begin{tabular}{|c|c|c|c|c|}
\hline & $\mathrm{df}$ & MS & $F$ & $\mathrm{p}$ \\
\hline \multicolumn{5}{|l|}{ Mugilidae } \\
\hline \multicolumn{5}{|l|}{ Between subjects } \\
\hline Tide & 1 & 38.8025 & 4.3890 & 0.0442 \\
\hline Habitat & 1 & 4.9692 & 0.5621 & 0.4589 \\
\hline Tide $\times$ Habitat & 1 & 2.9900 & 0.3382 & 0.5649 \\
\hline Error & 32 & 8.8408 & & \\
\hline \multicolumn{5}{|l|}{ Within subjects } \\
\hline Hour & 3 & 37.1058 & 12.0684 & ${ }^{\mathrm{I}} 0.0000$ \\
\hline Hour $\times$ Tide & 3 & 6.7261 & 2.1876 & ${ }^{\mathrm{\top}} 0.1186$ \\
\hline Hour $\times$ Habitat & 3 & 4.7863 & 1.5567 & ${ }^{\mp} 0.2179$ \\
\hline Hour $\times$ Tide $\times$ Habitat & 3 & 7.5618 & 2.4594 & ${ }^{\mp} 0.0915$ \\
\hline Error & 96 & 3.0746 & & \\
\hline \multicolumn{5}{|l|}{$\begin{array}{l}\text { Rhabdosargus holubi } \\
\text { Between subjects }\end{array}$} \\
\hline Tide & 1 & 0.1914 & 0.0211 & 0.8854 \\
\hline Habitat & 1 & 10.6984 & 1.1792 & 0.2856 \\
\hline Tide $\times$ Habitat & 1 & 28.2227 & 3.1108 & 0.0873 \\
\hline Error & 32 & 9.0725 & & \\
\hline \multicolumn{5}{|l|}{ Within subjects } \\
\hline Hour & 3 & 12.0039 & 6.6377 & ${ }^{\mathrm{I}} 0.0047$ \\
\hline Hour $\times$ Tide & 3 & 0.4703 & 0.2601 & ${ }^{\mathrm{\Phi}} 0.7257$ \\
\hline Hour $\times$ Habitat & 3 & 2.4958 & 1.3801 & ${ }^{\mp} 0.2584$ \\
\hline Hour $\times$ Tide $\times$ Habitat & 3 & 3.5294 & 1.9516 & ${ }^{\mp} 0.1597$ \\
\hline Error & 96 & 1.8085 & & \\
\hline \multicolumn{5}{|l|}{ Atherina breviceps } \\
\hline \multicolumn{5}{|l|}{ Between subjects } \\
\hline Tide & 1 & 384.323 & 1.5679 & 0.2196 \\
\hline Habitat & 1 & 147.521 & 0.6018 & 0.4436 \\
\hline Tide $\times$ Habitat & 1 & 1071.198 & 4.3700 & 0.0446 \\
\hline Error & 32 & 245.125 & & \\
\hline \multicolumn{5}{|l|}{ Within subjects } \\
\hline Hour & 3 & 241.890 & 1.9570 & 0.1256 \\
\hline Hour $\times$ Tide & 3 & 242.599 & 1.9627 & 0.1247 \\
\hline Hour $\times$ Habitat & 3 & 140.181 & 1.1341 & 0.3393 \\
\hline Hour $\times$ Tide $\times$ Habitat & 3 & 244.652 & 1.9793 & 0.1222 \\
\hline Error & 96 & 123.605 & & \\
\hline \multicolumn{5}{|l|}{ Gobiidae } \\
\hline \multicolumn{5}{|l|}{ Between subjects } \\
\hline Tide & 1 & 7.7934 & 14.5658 & 0.0006 \\
\hline Habitat & 1 & 1.8906 & 3.5336 & 0.0693 \\
\hline Tide $\times$ Habitat & 1 & 0.4444 & 0.8307 & 0.3689 \\
\hline Error & 32 & 0.5351 & & \\
\hline \multicolumn{5}{|l|}{ Within subjects } \\
\hline Hour & 3 & 2.4387 & 14.7053 & ${ }^{\mp} 0.0000$ \\
\hline Hour $\times$ Tide & 3 & 0.7992 & 4.8192 & ${ }^{\mp} 0.0139$ \\
\hline Hour $\times$ Habitat & 3 & 1.1140 & 6.7176 & ${ }^{\mp} 0.0032$ \\
\hline Hour $\times$ Tide $\times$ Habitat & 3 & 0.4456 & 2.6870 & ${ }^{\mp} 0.0816$ \\
\hline Error & 96 & 0.1658 & & \\
\hline
\end{tabular}

occasionally 'Feeding' and 'Start Stop' (Table 4). There were no discernable patterns in the behaviour of mugilids with regards to both the incoming tide and increasing depth, or habitat (Table 4). 
Table 4. Mugilidae, Rhabdosargus holubi, Atherina breviceps, Gobiidae. Percentage contribution of each behavioural category for the 4 most common taxa recorded within Bushmans Estuary in both sand and seagrass habitats over the 4 hours of the incoming Neap and Spring tides. Italicised numbers in parentheses show the number of observations from which the percentage contributions were generated from for each hour. Numbers in bold represent the dominant behaviour for each hour

\begin{tabular}{|c|c|c|c|c|c|c|c|c|}
\hline \multirow{2}{*}{ Behaviour } & \multirow[b]{2}{*}{ Hour 1} & \multirow{2}{*}{$\begin{array}{l}\text { Hour } 2 \\
\text { S }\end{array}$} & \multirow{2}{*}{$\mathrm{d}$} & \multirow[b]{2}{*}{ Hour 4} & \multirow[b]{2}{*}{ Hour 1} & \multirow{2}{*}{\multicolumn{2}{|c|}{\begin{tabular}{ll} 
& \multicolumn{2}{c}{ Seagrass } \\
Hour 2 & Hour 3
\end{tabular}}} & \multirow[b]{2}{*}{ Hour 4} \\
\hline & & & & & & & & \\
\hline \multicolumn{9}{|l|}{ NEAP TIDE } \\
\hline Mugilidae & $(0)$ & $(92)$ & $(94)$ & $(85)$ & $(0)$ & $(4)$ & $(49)$ & (55) \\
\hline Slow Meander & 0 & 27 & 21 & 33 & 0 & 0 & 59 & 53 \\
\hline Start Stop & 0 & 0 & 52 & 1 & 0 & 0 & 0 & 0 \\
\hline Rapid Swim & 0 & 55 & 27 & 55 & 0 & 0 & 18 & 27 \\
\hline Feeding & 0 & 17 & 0 & 11 & 0 & 100 & 22 & 20 \\
\hline Rhabdosargus holubi & $(0)$ & (19) & $(38)$ & $(32)$ & $(2)$ & $(16)$ & (39) & $(67)$ \\
\hline Slow Meander & 0 & 11 & 21 & 28 & 0 & 19 & 62 & 61 \\
\hline Start Stop & 0 & 5 & 5 & 0 & 0 & 13 & 10 & 10 \\
\hline Rapid Swim & 0 & 63 & 58 & 66 & 100 & 6 & 28 & 16 \\
\hline Feeding & 0 & 21 & 16 & 6 & 0 & 63 & 0 & 12 \\
\hline Atherina breviceps & (11) & $(21)$ & $(16)$ & (17) & $(35)$ & (15) & $(4)$ & $(12)$ \\
\hline Slow Meander & 27 & 38 & 63 & 41 & 29 & 73 & 50 & 83 \\
\hline Start Stop & 0 & 0 & 6 & 0 & 26 & 0 & 25 & 8 \\
\hline Rapid Swim & 73 & 62 & 31 & 53 & 11 & 27 & 25 & 8 \\
\hline Feeding & 0 & 0 & 0 & 6 & 34 & 0 & 0 & 0 \\
\hline Gobiidae & $(74)$ & (29) & $(17)$ & (19) & $(23)$ & $(26)$ & $(17)$ & $(11)$ \\
\hline Slow Meander & 0 & 0 & 0 & 0 & 0 & 0 & 0 & 0 \\
\hline Start Stop & 84 & 97 & 100 & 100 & 91 & 88 & 76 & 100 \\
\hline Rapid Swim & 0 & 0 & 0 & 0 & 4 & 4 & 0 & 0 \\
\hline Feeding & 16 & 3 & 0 & 0 & 4 & 8 & 24 & 0 \\
\hline \multicolumn{9}{|l|}{ SPRING TIDE } \\
\hline Mugilidae & $(0)$ & $(1)$ & $(18)$ & $(38)$ & $(7)$ & $(10)$ & $(32)$ & $(70)$ \\
\hline Slow Meander & 0 & 0 & 56 & 18 & 14 & 20 & 19 & 54 \\
\hline Start Stop & 0 & 0 & 0 & 3 & 0 & 0 & 0 & 0 \\
\hline Rapid Swim & 0 & 100 & 28 & 47 & 57 & 50 & 50 & 27 \\
\hline Feeding & 0 & 0 & 17 & 32 & 29 & 30 & 31 & 19 \\
\hline Rhabdosargus holubi & $(0)$ & $(0)$ & $(2)$ & $(2)$ & (11) & $(20)$ & $(54)$ & $(84)$ \\
\hline Slow Meander & 0 & 0 & 0 & 0 & 18 & 45 & 78 & 77 \\
\hline Start Stop & 0 & 0 & 0 & 0 & 73 & 35 & 6 & 6 \\
\hline Rapid Swim & 0 & 0 & 100 & 100 & 9 & 20 & 13 & 15 \\
\hline Feeding & 0 & 0 & 0 & 0 & 0 & 0 & 4 & 1 \\
\hline Atherina breviceps & $(4)$ & (17) & $(8)$ & (3) & $(18)$ & $(48)$ & (39) & $(4)$ \\
\hline Slow Meander & 75 & 29 & 25 & 33 & 83 & 63 & 79 & 50 \\
\hline Start Stop & 0 & 0 & 0 & 0 & 11 & 2 & 0 & 25 \\
\hline Rapid Swim & 25 & 71 & 75 & 67 & 6 & 35 & 21 & 25 \\
\hline Feeding & 0 & 0 & 0 & 0 & 0 & 0 & 0 & 0 \\
\hline Gobiidae & $(27)$ & (9) & $(7)$ & (9) & (11) & (4) & (2) & (1) \\
\hline Slow Meander & 0 & 0 & 0 & 0 & 0 & 0 & 0 & 0 \\
\hline Start Stop & 100 & 100 & 100 & 67 & 91 & 100 & 100 & 100 \\
\hline Rapid Swim & 0 & 0 & 0 & 33 & 0 & 0 & 0 & 0 \\
\hline Feeding & 0 & 0 & 0 & 0 & 9 & 0 & 0 & 0 \\
\hline
\end{tabular}

\section{DISCUSSION}

The abundance of some taxa, as well as the overall assemblage at subtidal seagrass edges and bare sand, showed considerable variation at small temporal scales that can be directly related to environmental changes associated with tides. More importantly, differences in abundances between seagrass edges and bare sand were contingent on tidal stage or tidal cycle (neap or spring). Our results are similar to previous studies within intertidal zones (Bretsch \& Allen 2006, Ellis \& Bell 2008), suggesting that tidal migrations resulting in highly dynamic fish assemblages in such habitats, also extend to the subtidal habitats 
investigated in this study. Additionally, our approach also allowed further behavioural insights into patterns of movement relative to tidally-driven changes in depth.

A number of processes may be responsible for driving the small temporal-scale patterns recorded along seagrass edges and at bare sand sites in the Bushmans Estuary. Abundances of Gobiidae consistently decreased with the incoming tide in both habitats, during both tidal cycles. Although it cannot be confirmed with our sampling design, it is likely that these species moved from the subtidal areas where filming occurred and migrated laterally into adjacent, newly inundated intertidal areas. The species comprising the family Gobiidae in this study (Psammogobius knysnaensis and Glossogobius callidus) are estuarine (Whitfield 1998). These types of small species undergo regular migrations of considerable distance into intertidal marsh habitats (Kneib \& Wagner 1994, Thomas \& Connolly 2001). The short interval between abundance calculations (15 min) shows that there is not a sudden exodus by the gobies at a particular tidal stage or depth, but rather a gradual decrease in abundance over the incoming tide. Predator avoidance is a regularly cited reason for small fish to depart subtidal habitats and migrate into intertidal zones (Rypel et al. 2007), but little direct evidence was obtained to support this hypothesis in the case of the gobies. Indeed, out of $144 \mathrm{~h}$ of collected footage, no piscivores were seen at any water depth or habitat. Also, other small bodied fish (Atherina breviceps) which are known prey of common piscivores (Whitfield \& Blaber 1978) showed no changes in abundance within these subtidal areas throughout most deployments.

Both Rhabdosargus holubi and the mugilids showed the opposite pattern in abundance, with increasing numbers observed over the incoming tide. Without stereo cameras it was not possible to accurately measure individuals (Watson et al. 2009), however R. holubi and the various species within the family Mugilidae were clearly considerably larger than the departing gobies. Ruiz et al. (1993) studied the depth-related distribution of fish within Chesapeake Bay and found a significant decrease in the abundance of largebodied nekton in progressively shallower water and suggested that shallow depths restricted the access of larger individuals. While our study corroborates these size-depth relationships, by filming continuously as depths changed, we found evidence of a potential depth threshold for these larger taxa. Unlike the departing gobies, $R$. holubi and the mugilids showed a clear increase in abundance $2 \mathrm{~h}$ into deployments when depths exceeded $50 \mathrm{~cm}$, followed by a sustained increase in abundance. A key finding from the few published tidal studies using high frequency sampling is that different species do not enter a habitat together. Rather the responses are species-specific with many, particularly larger species and larger size classes within species, not moving into intertidal areas until late in the tidal cycle (Bretsch \& Allen 2006, Ellis \& Bell 2008). Habitat type had no influence on the tidal stage at which this threshold appeared to occur, with both taxa observed at seagrass edges and bare sand at approximately the same point in the tide. It is possible that we were only observing the mugilids and $R$. holubi as they migrated towards the intertidal zone. However their maintained elevated abundances in depths above $60 \mathrm{~cm}$ suggests that these habitats are themselves of intrinsic value and not simply transitional zones.

No consistent changes in fish abundance or assemblage between bare sand and seagrass edges were detected, and when differences between habitats were found, they interacted with other factors, such as 'Tide Cycle' or 'Hour'. The effects of seagrass edges on the distribution of fishes have been inconsistent with both positive and negative associations previously reported (Jelbart et al. 2006, Smith et al. 2008, Macreadie et al. 2009). These effects can also interact with other factors such as patch size (Smith et al. 2010). Many of the species reported in this study were more mobile than those investigated in other seagrass edge effect studies, and therefore, rapid and constant movements between bare sand and seagrass edges may explain some of our results. However, we did find evidence that association of fishes with edge habitat may be influenced by small changes in water depth. Abundances of gobies were higher in bare sand than at seagrass edges early in the tide at shallow depths. By the third hour of the incoming tide, while overall abundance had dropped, there were no longer differences between the sand and seagrass edges. This highlights a small temporal-scale dynamic which may influence the association of fishes with habitat edges. Given the lack of direct evidence, it is difficult to link this pattern directly to predator avoidance, but it may be that the gobies occupying these vegetated sites during deeper depths may have perceived an increase in predator threat (Brown et al. 2006) and mostly abandoned the bare sand.

There were more Atherina breviceps at the seagrass edges than bare sand during spring tides, yet the opposite pattern was observed in neap tides. An explanation for this may be that the seagrass was 
breaking up the high velocity currents (Granata et al. 2001) during spring tides. The seagrass edges were located on the upstream side of the beds and may have created low velocity refuges for these small fish. Recorded currents within the lower Bushmans Estuary during spring tide cycles are constantly higher $\left(\right.$ mean $\pm \mathrm{SE}=0.33 \pm 0.01 \mathrm{~m} \mathrm{~s}^{-1}$ ) than during neap cycles $\left(0.20 \pm 0.01 \mathrm{~m} \mathrm{~s}^{-1}\right)$. Higher abundance of $A$. breviceps at seagrass edge sites during spring tides was also largely responsible for the Tide $\times$ Habitat interaction in the overall fish assemblage.

The changes in abundance of the 4 common species over the incoming tide also resulted in a change in the overall fish assemblage which was reflected by the significant main effects of Hour in the multivariate analysis. The other notable species contributing to the assemblage pattern was Diplodus capensis, which is similar in morphology and size to Rhabdosargus holubi and also increased in abundance at deeper depths later in the tide. Higher abundance that habitat partitioning at small temporal intervals can exist within a range of fish species occupying littoral seagrass beds and bare sand.

Gear bias is a critical issue in any study of fish. New technology, such as underwater cameras, allows fish abundances to be calculated at very small time intervals. Previous tidal studies have mostly employed netting (e.g. Thomas \& Connolly 2001) making it difficult to collect data at these temporal scales. Indeed, it is likely that the patterns observed in the present study could only be documented using recent technological advances. However, underwater cameras have their own restrictions and bias. Similar to other passive methods, underwater video relies on fish movement to be detected, and species identification can be difficult or impossible. Only 12 taxa were recorded to species level, so we were forced to group others at the family level. Additionally cryptic species are also likely to be under-represented in video studies because of their reduced mobility and camouflage. Video obstruction caused by the seagrass blades also resulted in our study being restricted to seagrass edges, and underwater cameras are unlikely to provide reliable data from dense structured habitats.

This study was conducted at scales of 10s to 100s of meters, and although our study was not designed to test for variation among sites, these differences were apparent. This highlights the spatial heterogeneity of fishes at small scales and may point to small changes in shoot density among beds (Smith et al. 2008) or local variability in their food resources (Macreadie et al. 2010). Despite this local variability, there was still consistency in the response of fish to the incoming tide over a spatial area of $700 \mathrm{~m}$. Whether these observations are peculiar to this estuary, fish species, or subtidal landscape remains unknown until similar studies are performed at larger scales and at other locations. Further studies could provide useful information by incorporating a number of estuaries to test the effects of various spatial scales.

The behavioural approach adopted by this study was unique and provided additional insights into the observed patterns of fish abundance during neap and spring tides. Comparisons among habitats often showed distinct variation for some taxa, however this behaviour differed little over the incoming tide. It appears that although water depth can have significant effects on the abundances of fishes within both seagrass and bare sand, it has little influence on the actual behaviour of those fishes regardless of their numbers.

In the nearby East Kleinemonde Estuary, Becker et al. (2010) observed changes in fish behaviour between structured (Phragmites australis and reef) and unstructured habitat (bare sand). The results of the current study add further evidence that different habitats can affect the behaviours of fishes, even as water depths change. The East Kleinemonde study documented Rhabdosargus holubi and Atherina breviceps as mostly displaying rapid swimming behaviour over bare sand, while in structured habitat, slow meandering was the dominant behaviour. Similar results obtained during this study suggest that there is generally a strong behavioural response related to habitat structure that is little affected by depth.

Mugilids did not display clear behavioural patterns associated with the 2 habitats, which contrasts with Becker et al. (2010). Unlike Rhabdosargus holubi and Atherina breviceps, which appear to show a general behavioural response to structure, mugilids may respond differently to seagrass beds compared to the stands of Phragmites australis and reef within the East Kleinemonde Estuary. Mugilids were often seen feeding, and this was more common along seagrass edges than on bare sand, where they were often seen feeding both directly off the seagrass leaf blades and the sand immediately next to the seagrass beds. While it may not be the exclusive reason for their movement into these littoral areas, the video footage provides evidence that feeding was at least an activity undertaken in these areas and that these areas are providing services for fish.

In conclusion, the use of an underwater camera has facilitated the collection of both continuous fish assemblage data and allowed the simultaneous investigation of fish behaviour within the littoral zone 
over incoming tides. For some taxa, behaviour differed between seagrass edges and sand, but was similar at different water depths. Patterns in the abundance or assemblages of fish in seagrass landscapes have been measured according to a number of spatial and temporal aspects (Connolly \& Hindell 2006). Our findings demonstrate that small changes in water depth due to tides caused variable abundance of common fish taxa. Furthermore, when differences existed in fish abundance along seagrass edges and at bare sand sites, fish were influenced by small changes in water depth or to changing tidal cycles. These are mostly overlooked aspects that may be as important as the various spatial (e.g. patch size, proximity to neighbouring habitat) and temporal factors (e.g. diel, seasonal) previously investigated and are likely to greatly influence fish assemblages associated with littoral seagrass landscapes. Further interesting results could be obtained by expanding this study to include multiple estuaries. This would allow the interaction of small and large scale factors to be tested and potentially strengthen the generality of these findings.

Acknowledgements. A Claude Leon post-doctoral fellowship was awarded to A.B. and running costs were provided by the National Research Foundation (NRF) and South African Institute for Aquatic Biodiversity (SAIAB). P. Cowley provided the underwater camera and helpful advice throughout the course of the project. We thank V. Cole who provided comments on the manuscript and statistical approach and are grateful for the field support from K. Pieterse, F. van der Vyver, R. Field, N. Robinson, R. Wartenberg, G. Taylor, B. Ellender, M. Parkinson and V. Cole. Comments and suggestions from the 3 reviewers also helped to improve the original manuscript.

\section{LITERATURE CITED}

Anderson MJ, Gorley RN, Clark KL (2008) PERMANOVA+ for PRIMER: guide to software and statistical methods. PRIMER-E, Plymouth

> Becker A, Cowley PD, Whitfield AK (2010) Use of remote underwater video to record littoral habitat use by fish within a temporarily closed South African estuary. J Exp Mar Biol Ecol 391:161-168

Becker A, Cowley PD, Whitfield AK, Järnegren J, Næsje TF (2011) Diel fish movements in the littoral zone of a temporarily closed South African estuary. J Exp Mar Biol Ecol 406:63-70

Bell JD, Ferrell DJ, McNeill SE, Worthington DG (1992) Variation in assemblages of fish associated with deep and shallow margins of the seagrass Posidonia australis. Mar Biol 114:667-676

Bretsch K, Allen DM (2006) Tidal migrations of nekton in salt marsh intertidal creeks. Estuaries Coasts 29:474-486

$>$ Brown GE, Rive AC, Ferrari MCO, Chivers DP (2006) The dynamic nature of antipredator behavior: prey fish integrate threat-sensitive antipredator responses within background levels of predation risk. Behav Ecol Sociobiol 61:9-16

- Cappo M, De'ath G, Speare P (2007) Inter-reef vertebrate communities of the Great Barrier Reef Marine Park determined by baited remote underwater video stations. Mar Ecol Prog Ser 350:209-221

- Cole VJ, McQuaid CD (2010) Bioengineers and their associated fauna respond differently to the effects of biogeography and upwelling. Ecology 91:3549-3562

Connolly RM, Hindell JS (2006) Review of nekton patterns and ecological processes in seagrass landscapes. Estuar Coast Shelf Sci 68:433-444

Ellis WL, Bell SS (2004) Conditional use of mangrove habitats by fishes: depth as a cue to avoid predators. Estuaries 27:966-976

Ellis WL, Bell SS (2008) Tidal influence on a fringing mangrove intertidal fish community as observed by in situ video recording: implications for studies of tidally migrating nekton. Mar Ecol Prog Ser 370:207-219

Giarrizzo T, Krumme U, Wosniok W (2010) Size-structured migration and feeding patterns in the banded puffer fish Colomesus psittacus (Tetraodontidae) from north Brazilian mangrove creeks. Mar Ecol Prog Ser 419:157-170

$>$ Gibson RN (2003) Go with the flow: tidal migration in marine animals. Hydrobiologia 503:153-161

> Granata TC, Serra T, Colomer J, Casamitjana X, Duarte CM, Gacia E (2001) Flow and particle distributions in a nearshore seagrass meadow before and after a storm. Mar Ecol Prog Ser 218:95-106

Hampel H, Cattrijsse A, Vincx M (2003) Tidal, diel and semilunar changes in the faunal assemblage of an intertidal salt marsh creek. Estuar Coast Shelf Sci 56:795-805

Hovel KA, Fonseca MS, Myer DL, Kenworthy WJ, Whitfield PE (2002) Effects of seagrass landscape structure, structural complexity and hydrodynamic regime on macrofaunal densities in North Carolina seagrass beds. Mar Ecol Prog Ser 243:11-24

Jackson EL, Rowden AS, Attrill MJ, Bossey S, Jones M (2001) The importance of seagrass beds as habitat for fishery species. Oceanogr Mar Biol Annu Rev 39: 269-303

> Jackson EL, Attrill MJ, Jones MB (2006) Habitat characteristics and spatial arrangement affecting the diversity of fish and decapod assemblages of seagrass (Zostera marina) beds around the coast of Jersey (English Channel). Estuar Coast Shelf Sci 68:421-432

> Jelbart JE, Ross PM, Connolly RM (2006) Edge effects and patch size in seagrass landscapes: an experimental test using fish. Mar Ecol Prog Ser 319:93-102

Kimball ME, Able KW (2007) Nekton utilization of intertidal salt marsh creeks: tidal influences in natural Spartina, invasive Phragmites, and marshes treated for Phragmites removal. J Exp Mar Biol Ecol 346:87-101

- Kneib RT, Wagner SL (1994) Nekton use of vegetated marsh habitats at different stages of tidal inundation. Mar Ecol Prog Ser 106:227-238

> Macreadie PI, Hindell JS, Jenkins GP, Connolly RM, Keough MJ (2009) Fish response to experimental fragmentation of seagrass habitat. Conserv Biol 23:644-652

> Macreadie PI, Hindell JS, Keough MJ, Jenkins GP, Connolly RM (2010) Resource distribution influences positive edge effects in a seagrass fish. Ecology 91:2013-2021

Quinn GP, Keough MJ (2002) Experimental design and data analysis for biologists. Cambridge University Press, 
Cambridge

Rozas LP, Zimmerman RJ (2000) Small-scale patterns of nekton use among marsh and adjacent nonvegetated areas of the Galverston Bay Estuary, Texas (USA). Mar Ecol Prog Ser 193:217-239

Ruiz GM, Hines AH, Posey MH (1993) Shallow water as a refuge habitat for fish and crustaceans in non-vegetated estuaries: an example from Chesapeake Bay. Mar Ecol Prog Ser 99:1-16

Rypel AL, Layman CA, Arrington DA (2007) Water depth modifies relative predation risk for a motile fish taxon in Bahamian tidal creeks. Estuaries Coasts 30:518-525

Smith TM, Hindell JS, Jenkins GP, Connolly RM (2008) Edge effects on fish associated with seagrass and sand patches. Mar Ecol Prog Ser 359:203-213

Smith TM, Hindell JS, Jenkins GP, Connolly RM (2010) Seagrass patch size affects fish responses to edges. J Anim Ecol 79:275-281

Smith TM, Hindell JS, Jenkins GP, Connolly RM, Keough MJ (2011) Edge effects in patchy seagrass landscapes: the role of predation in determining fish distribution. J Exp Mar Biol Ecol 399:8-16

Sogard SM, Powell VN, Holmquist JG (1989) Utilization by

Editorial responsibility: Ivan Nagelkerken,

Nijmegen, The Netherlands fishes of shallow, seagrass covered banks in Florida Bay: 2. Diel and tidal patterns. Environ Biol Fishes 24:81-92

Thomas BE, Connolly RM (2001) Fish use of subtropical saltmarshes in Queensland, Australia: relationships with vegetation, water depth and distance onto the marsh. Mar Ecol Prog Ser 209:275-288

Unsworth RKF, Bell JJ, Smith DJ (2007) Tidal fish connectivity of reef and sea grass habitats in the Indo-Pacific. J Mar Biol Assoc UK 87:1287-1296

> Watson DL, Anderson MJ, Kendrick GA, Nardi K, Harvey ES (2009) Effects of protection from fishing on the lengths of targeted and non-targeted fish species at the Houtman Abrolhos Islands, Western Australia. Mar Ecol Prog Ser 384:241-249

Whitfield AK (1998) Biology and ecology of fishes in southern African estuaries. Ichthyol Monogr JLB Smith Inst Ichthyol 2:1-223

- Whitfield AK (2005) Fishes and freshwater in southern African estuaries - a review. Aquat Living Resour 18: 275-289

Whitfield AK, Blaber SJM (1978) Food and feeding ecology of piscivorous fishes at Lake St Lucia, Zululand. J Fish Biol 13:675-691

Submitted: September 21, 2011; Accepted: February 29, 2012 Proofs received from author(s): May 23, 2012 